\title{
İlköğretim II. Kademe Öğrencileri İçin Çevre Okuryazarlığı Ölçeği: Ölçek Geliştirme ve Güvenirlik
}

\author{
Çalışması
}

\author{
Melike YAVUZ* \\ Fatime BALKAN KIYICI ${ }^{* *}$ Elif ATABEK YİĞİT*** \\ Öz
}

Bu araştırmada ilköğretim ikinci kademe öğrencilerinin çevre okuryazarlıklarını belirlemeye yönelik bir ölçek geliştirilmesi amaçlanmıştır. Araştırmanın çalışma grubunu; 2010 - 2011 bahar yarıyılında 6 farklı ilköğretim okulunun ikinci kademesinde öğrenim gören toplam 377 öğrenci oluşturmaktadır. İlk olarak araştırmacılar tarafından 45 soruluk bir madde havuzu oluşturulmuştur. Uzman görüşleri alınarak gerekli düzeltmeler yapıldıktan sonra 39 maddeden oluşan bir deneme formu elde edilmiştir. Bu formun uygulanmasının ardından yapılan açımlayıcı faktör analizi sonuçlarına göre iki boyuttan (davranış ve tutum) oluşan 20 maddelik 5'li Likert tipi ölçek elde edilmiştir. Hazırlanan ölçeğin güvenirlilik çalışmaS1 sonucunda tüm ölçek için Cronbach Alpha katsayısı. 84 olarak bulunmuştur.

Anahtar Kelimeler: Çevre okuryazarlı̆̆̆, Ölçek geliştirme, İlköğretim öğrencileri.

\section{Environmental Literacy Scale For Secondary School Stu- dents: The Scale Development And Reliability}

\begin{abstract}
The purpose of the research is to develop a scale to determine secondary school students' environmental literacy levels. The sample of the research was consisted of 377 students of six public secondary schools. The study was done in 2010-2011 spring semester. The researchers first of all created an item pool that consists of 45 items. A draft form with 39 items was created after the necessary corrections had been made based on the expert opinions. The results of the Explanatory Factor Analysis on a 20 item five- point Likert type scale showed that the instrument consists of two dimensions those attitude and behaviour. Moreover reliability analysis of the instrument revealed Cronbach-Alpha coefficient of .84 for the whole scale.
\end{abstract}

Anahtar Kelimeler: Environmental literacy, Scale development, Secondary school students.

\footnotetext{
* Sakarya Üniversitesi, İlköğretim Fen Bilgisi Eğitimi Bölümü, Doktora Öğrencisi

** Doç. Dr., Sakarya Üniversitesi, İlköğretim Fen Bilgisi Eğitimi Bölümü, fbalkan@sakarya.edu.tr

*** Yrd. Doç. Dr., Sakarya Üniversitesi, İlköğretim Fen Bilgisi Eğitimi Bölümü, eatabek@sakarya.edu.tr
} 


\section{GİRIŞ}

İnsanlar yaşama şekillerinden dolayı her zaman bulunduğu ortamı etkilemiş ve bu ortamdan etkilenmiştir. Bu yüzden çevre kavramından bahsedildiğinde ilk olarak insanların akl1na içinde bulundukları ortam ve bu ortama yakın olan yerler gelmektedir. Oysa ki günümüz koşullarında; hızlı ilerleyen bilimsel çalı̧̧malar ve insanoğlunun doğaya hükmetme çabasıyla birlikte, çevre kavramı bu dar kalıptan çıkarak çok daha geniş anlamlara sahip olmuştur. Bu bağlamda Yücel ve Morgil (1998)' e göre çevre "bir canlı organizmayı veya bir canlı topluluğu yaşama süresince etkileyen her türlü, biyotik ve abiyotik (sosyal, kültürel, tarihsel, iklimsel, fiziksel) faktörlerin tümü" olarak açıklanmıştır.

Yapılan tanımdan yola çıkarak çevrenin tüm canlı varlıkların yaşamlarını etkileyen ve insanla etkileşim halinde olan bir unsur olduğu söylenebilir. Bu etkileşimler sırasında insanlar; doğaya hükmetmeye ve bulundukları çevreyi kendi yaşantılarına göre düzenlemeye çalışmaları sonucunda çevre sorunlarıyla karşı karşıya kalmıştır. Özellikle 19. yy'da gerçekleşen sanayi devrimine bağlı olarak, hızlı nüfus artışı ve endüstriyel alanda yer alan yenilikler ve gelişmeler sonucunda bireylerin çevreye olan gereksinimleri artmıştır. Dolayısıyla; bireylerin bu ihtiyaçları doğal dengenin bozulmasına yol açarak birçok çevre sorununun ortaya çıkmas1na neden olmuştur. (Kışoğlu, 2009; Selvi, 2007). Çevre sorunlarının sayısındaki hızlı artışa bağlı olarak uzmanlar çevre sorunlarıyla başa çıkma yollarını aramaya başlamıştır. Bunun üzerine çevreyle alakalı birçok konferans düzenlemiş, anlaşmalar yapılmış ve bildirge ve yasalar hazırlanmıştır (Güneş, 2001; Kiss ve Shelton, 1991; Turan ve Güler, 2013; UNESCO, 1977). Bunlardan şüphesiz en önemlileri Stockholm'da düzenlenen Birinci Çevre Konferansı ve Tiflis Bildirgesi'dir. Her ikisinde de üzerinde durulan konulardan bir tanesi çevre eğitimi olmuştur. Çevre sorunlarıyla başa çıkmanın en iyi yolunun çevreye duyarlı vatandaşlar yetiştirmek olduğunun farkına varılmıştır (Balkan Kıyıcı, 2009; Kışoğlu, 2009).

Her geçen gün artan çevre sorunlarını çözebilmek için teknoloji, yasa ve kanunlar tek başına yeterli değildir. Bilinçli, planlı ve kalıcı yaklaşımlar ortaya koyan eğitimde, temel çevre sorunlarının çözümlenmesinde yer alan bir başka önemli ve gerekli unsurdur. Çünkü; çevre eğitimi sayesinde bireyin çevresine karş1 olumlu tutum ve değer yargıları geliştirilmesi sağlanır (Erten, 2005). Sorunlarla başa çıkabilmenin ve sorunların çımasını engellemenin en kolay ve başarılı yolu eğitimden geçmektedir. Çevre sorunları hakkında gerekli duyarlılık ve farkındalık düzeyine ulaşılmasını sağlayan çevre eğitimi ile; bireyler çevre sorunlarını ortadan kaldırmaya yönelik çözüm yolları üretme ve çevreyle ilgili gerekli bilgi ve becerilere bağlı uygun davranış ve tutumları sergileme sürecine dahil edilmektedirler (UNESCO; 1977).

Ülkemizde de çevre eğitimine verilen önem Tiflis Bildirgesi ile hız kazanmıştır. Çevre eğitiminin önem kazanmasılyla birlikte; çevre sorunlarının önüne geçilmesinde etken rol oynayan faktörün insanoğlu olduğu açı bir şekilde ortadadır (Gündüz, 1998). Doğada bulunan bütün canlılar dengenin bozulmaması için olumlu yönde katkılar sağlarken, maalesef ki insanoğlu kendi çıkarları doğrultusunda bilinçsizce çevre üzerinde yaptığı bazı değişikler ve bıraktığı olumsuz etkiler sonucunda çevreyi olumsuz etkilemektedir. Her yaştaki bireyler için çevre eğitimi önemlidir, ancak özellikle çocuklar çevre eğitimi için çok önemli bir kitleyi oluşturur; çünkü onlar yarınların liderleri ve tüketicileridir (Braus ve Wood, 1993). Ayrıca çocuklar eski nesillere göre yeni- 
liklere daha açıktır ve yaratıcılık potansiyelleri vardır, bu sayede çevreyi korumak için davranışlar kazanabilirler (Trudel, 1995). Bu davranışların bireylerde bir yaşam tarzına dönüşmesi açısından erken yaşta kazanılması son derece önemlidir. Çünkü bireylerin okul öncesinde kazandığı çevre bilgisi ve çevreye yönelik tutumları gelecek yıllarda var olacak çevreye karşı davranış ve tutumlarına yol gösterici olacaktır (Smith, 2001). İşte bu yüzden çevre eğitiminin aile ortamından başlayarak; okul öncesi eğitimden, tüm örgün ve yaygın eğitim aşamalarında, ömür boyu süren bir eğitim durumu haline getirilmesi çok önemlidir.

2005 yılı öncesi ilköğretim programında çevre ünitelerinin ağırlıklı olarak 4. ve 5. sınıf sosyal bilgiler ile 4, 6 ve 7 . sinif fen bilgisi derslerinde yoğunlaştığı görülmektedir. 2005 yılında Milli Eğitim Bakanlığı'nın yapılandırmacı yaklaşıma göre yeni hazırladığı fen ve teknoloji öğretim programı ile birlikte; öğrencilere doğayı tanıtma ve bilim, teknoloji, toplum ve çevre arasındaki ilişkiyi anlatmaya çalışmak amaçlanmıştır. Böylelikle programda yer alan dört ana alandan birisi insan ve çevre ile ilgili olarak uygulamaya konulmuştur (Alım, 2006). 2013 fen bilimleri programında ise; çevreye yönelik konulara 3. Sinıftan itibaren her sınıf düzeyinde yer verilmiştir. 2005 programından farklı olarak bu programda kaynakların tasarruflu kullanımı ve geri dönüşüm ile ilgili kazanım sayısı artırılmıştır (Özata Yücel ve Özkan, 2013). Düzenlenen çevre programlarıyla amaçlanan; okul öncesi eğitimden başlayarak bireyin yaşam boyu uygulayacağı davranışları ve bilinci kazandırmaktır. Bu sayede kişi, çevresel sorunlarının farkına vararak bu problemi çözebilecek çözüm yolları üretir ve temiz ve sağlıklı bir çevrenin hayatın kalitesi ve niteliğini artıracağının farkına varır (Soran, Morgil, Yücel, Atav ve Işık, 2000). Bu da ancak çevre konusunda bilgi ve farkındalığa sahip, duyarlı bireyler olan çevre okuryazarı bireyler yetiştirmekle mümkündür.

Çevre okuryazarlığı, bireyin çevre ile ilgili yaşam boyu öğrendiği bilgileri davranışa dönüştürebilme yeteneğidir (Roth, 1992). Bu bağlamda; çevreyle ilgili bilinçli davranışa sahip olan çevre okuryazarlığı yüksek bireylerin yetiştirilmesi çevre eğitimi ile hedeflenmektedir (Kışoğlu, Gürbüz, Sülün, Alaş ve Erkol; 2010). Günümüzde çevre sorunlarının ve bunların insanlara doğrudan ve dolaylı etkileri göz önünde bulundurulduğunda bireylerde çevre okuryazarlığı kapsamında olumlu tutum ve davranışların geliştirilmesi önem kazanmıştır. Fakat bireylerin sahip oldukları olumlu ya da olumsuz tutumlar onların davranışlarına her zaman yansımayabilir bu da bireylerin tutumlarını belirleyip davranışa dönüştürebilmek için araştırmaların yürütülmesi gereğini ortaya çıkarmaktadır. Dolayısıyla bu çalışma kapsaminda da tutum ve davranış alt boyutları göz önünde bulundurulmuştur.

Çevre sorunlarının başlıca sebepleri arasında insanların çevre konusunda yeterli bilgiye sahip olmaması, buna bağlı olarak da olumsuz tutum ve davranışlar geliştirdiği göz önüne alındığında, çevre okuryazarı bireyler yetiştirmenin çevre sorunlarını çözme ve önlemede çok önemli bir faktör olduğu söylenebilir. Bu sebepten bireylerin okuryazarlık durumlarının tespit edilmesi, okuryazar bireylerin yetiştirilmesi ve bunun önündeki engellerin tespit edilerek önlemlerin alınması yaşanılabilir bir çevre için önemli bir zorunluluktur. Ancak bu konu ile ilgili literatür incelendiğinde; literatürde yer alan ölçeklerin ve yapılan çalışmaların daha çok üniversite öğrencilerinin okuryazarlık düzeylerini tespit etmeye yönelik olduğu söylenebilir (Kibert, 2000; Sevinç, Balkan Kıyıcı, Altaş ve Altınöz, 2010; Ökesli, 2008). Çevreye karşı duyarlı bireylerin yetiştirilmesinde "A ğaç yaşken eğilir" mantığıyla hareket edilmesi, bu 
sürecin ailede başlayıp, okulöncesi ve ilköğretim kademesinden itibaren ele alınması ve gereken önemin verilmesi son derece önemlidir. Bu bağlamda bu araştırmada; ilköğretim ikinci kademe (ortaokul) öğrencilerinin çevre okuryazarlığı düzeylerini tespit etmek için bir ölçek geliştirmesi amaçlanmıştır. Çalışmada yeni bir ölçek geliştirme amacının en önemli nedeni; yerli literatürde var olan ölçeklerin genellikle daha büyük yaş gruplarına hitap eder nitelik taşıması veya çevre okuryazarlığının farklı boyutlarını ölçmeye yönelik olmasından kaynaklanmaktadır. Yabancı literatürdeki ölçeklerin uyarlanması şeklinde olmaması ise kendi kültürümüze uygun bir ölçek geliştirme çabasından kaynaklanmaktadır.

\section{YÖNTEM}

Araştırma bir ölçek geliştirme çalışmasıdır. Bu bölümde çalışma grubu ve ölçek geliştirme çalışmalarına yönelik bilgiler verilmiştir.

\section{1. Çalışma Grubu}

Araştırmanın çalışma grubunu, 2010 - 2011 yılında Sakarya İlinin Hendek İlçesi'nde bulunan okullar arasından basit seçkisiz seçim ile seçilen altı İlköğretim okulunda öğrenim gören 377 ilköğretim ikinci kademe öğrencisi oluşturmuştur. Yapılan incelemeler sonucunda çalışma grubunu oluşturan bu 377 öğrenciden alınan verilerden 348 tanesinin analiz edilebilir düzeyde olduğu saptanmıştır. Öğrencilerin maddeleri boş bırakması ya da bir maddeye aynı anda iki cevap vermesinden dolayı 29 adet ölçeğin çıartılması uygun bulunmuştur.

\section{2. Veri Toplama Aracının Geliştirilmesi}

Ölçeğin geliştirilmesi sırasında beş aşama izlenmiştir. $\mathrm{Bu}$ aşamalar, literatür taraması, madde havuzunun oluşturulması, uzman görüşlerinin alınması, uygulama, faktör analizi ve güvenirlik çalışması şeklindedir. İlk aşamada literatür taraması yapılarak çevre okuryazarlığı ve çevre bilincinin geliştirilmesiyle ilgili çevre okuryazarlığı ölçek geliştirme ve uyarlama çalışmaları incelenmiştir (Kaplowitz ve Levine, 2005; Kışoğlu, 2009; Tuncer, Tekkaya, Sungur, Çakıroglu, Ertepınar ve Kaplowitz, 2009; Selvi, 2007). İkinci aşamada yapılan bu incelemelerin ardından araştırmacılar tarafından çevre okuryazarlığının davranış ve tutum boyutlarını açıkladığı düşünülen 45 soruluk bir madde havuzu oluşturulmuştur. Üçüncü aşamada bu maddelerle ilgili olarak uzman görüşüne başvurulmuştur. Madde havuzundaki 45 madde 2 uzman (fen eğitimcisi) tarafından incelenmiştir. Uzman görüşleri doğrultusunda, 6 madde; açık olmadığı ve ifade eksikliğine yer verdiği için ölçekten çıkartılmıştır. Geriye kalan 39 maddenin de kendi içinde eksik kalan kısımları düzeltilmiştir. 39 maddelik bu ölçeğin 21 maddesi tutumu, 18 maddesi davranışı ölçmeye yönelik olup 35 madde olumlu, 4 madde olumsuz olarak ifade edilmiştir. Ölçeğin maddeleri 5'li Likert tipinde düzenlenmiştir. Maddeler; (5) kesinlikle katıliyorum, (4) katıliyorum, (3) kararsızım, (2) katılmıyorum, (1) kesinlikle katılmıyorum şeklinde derecelendirilmiştir. İstatistiksel işlemler yürütülmeden önce olumsuz olan 4 madde ters olarak kodlanmıştır. Sonucunda ilköğretim öğrencilerinin çevre okuryazarlığına ilişkin görüşlerinin alınmasını sağlayacak 39 maddeden oluşan beşli Likert tipi bir taslak ölçek oluşturulmuştur. Ölçeğin pilot çalışması yapılırken bir grup ilköğretim II. kademe öğrencisine uygulanmış ve tekrar uygunluk bakımından öğretmenlerin incelemesi sağlanmıştır. Daha sonra 377 öğrenciye uygulanan ölçekten elde edilen verilerden 348 tanesinin analiz edilebilir düzeyde olduğu saptanmış ve gerekli değerlendirmeler yapılmiştır.

\section{3. Verilerin Çözümlenmesi}

Ölçeğin yapı geçerliliğinin tespit edilmesi için açımlayıcı faktör analizi yapılmıştır. Açımlayıcı 
faktör analizi (AFA); değişkenler arasındaki ilişkilerden hareketle faktör bulmaya yönelik bir işlemdir (Büyüköztürk, 2011). Faktör analizinde üç ölçüt dikkate alınmıştır. Bunlar; faktör yük değerlerinin .30'dan büyük olması, yüksek yük değerliğine sahip olan maddelerin tek bir faktörde, düşük yük değerliğine sahip olan maddelerin ise diğer faktörler altında toplanması ve yapılan analizde öz değeri 1 ya da 1 'den büyük olan faktörlerin ele alınmasıdır (Büyüköztürk, 2011). Ayrıca ölçeğin güvenilirliğini belirlemek amacıyla iç tutarlılığının bir ölçüsü olan Cronbach Alpha değeri hesaplanmiştır.

AFA sonucu belirlenen ölçeğin faktör yapılarının doğrulanması amaciyla $\mathrm{AFA}^{\prime}$ da yer alan bireylerin dışında farklı bir örneklem grubuna ait veriler üzerinde doğrulayıcı faktör analizi (DFA) yürütülmüştür. LISREL programı ile model veri uyumunun analizinin değerlendirilmesi için Chi-Square $(\chi 2)$ / Serbestlik Derecesi (sd), Adjusted Goodness of Fit Index (AGFI), Goodness of Fit Index (GFI), Normed Fit Index (NFI), Non-Normed Fit Index (NNFI), Incremental Fit Index (IFI), Comparative Fit Index (CFI) ve Root- Mean-Square Error of Approximation (RMSEA) uyum iyiliği değerlerine bakılmıştır. Ortaya çıkan bu değerler var olan kriterlerle karşılaştırılarak yorumlanarak AFA sonucunda ortaya çıkan modelin uygunluğu test edilmiştir.

\section{BULGULAR}

Araştırmanın bu kısmında çevre okuryazarlığ ölçeğinin yapı geçerliliğini tespit etmek amacıyla açımlayıcı ve doğrulayıcı faktör analizi yürütülmüş ve güvenirlik için iç tutarlılık anlamina gelen Cronbach Alpha katsayısı hesaplanmıştır.

\subsection{Açımlayıcı faktör analizi (AFA)}

İlköğretim öğrencileri için çevre okuryazarlı̆̆1 ölçeğinin yapı geçerliliğini tespit etmek amacıyla açımlayıcı faktör analizi (AFA) yapılmıştır. Büyüköztürk'e (2011) göre; faktör analizi tüm veri yapıları için uygun olmayabilir. Verilerin uygunluğunu tespit etmek için; örneklem büyüklüğünün yeterliliğini gösteren $\mathrm{KMO}$ katsayısının ve Barlett küresellik testinin incelenmesi gerekmektedir. Faktör analizinin yapılabilmesi için KMO katsayısının .60' dan yüksek (Kaiser, 1974), Barlett testinin ise anlamlı çıkması ( $<<.05)$ gerekmektedir.Yapılan analiz sonuçlarına göre; ilk olarak KMO katsayısı ,87 bulunarak örneklem büyüklügünün yeterli olduğu görülmüştür. İkinci olarak ise; Barlett testine $(p=.000)$ bakılarak anlamlı farklılık gösterdiği tespit edilmiştir. Analiz sonuçlarına göre; veriler üzerinde faktör analizi yapılabileceği sonucuna varılmıştır.

Faktör analizi sırasında temel bileşenler analizi kullanılmıştır. Faktörlerin daha kolay yorumlanabilmesi ve kendileriyle yüksek ilişki veren maddeleri bulabilmesi için varimax döndürme kullanılmıştır. Varimax döndürme maddelerin yük değerini bir faktörde $1.0^{\prime}$ a, diğerlerinde ise 0.0'a yaklaştırmayı amaçlar (Büyüköztürk, 2011).

Ölçeğin tutum ve davranış olmak üzere 2 boyutu ölçmesi amaçlandığı için faktör analizi 2 boyutla sınırlandırılarak yapılmıştır. Yapılan analiz sonucunda faktör yükleri .30'un altında olan ve birden fazla boyutu açıklayan 19 madde ölçekten çıkartılarak faktör analizi tekrarlanmıştır. 


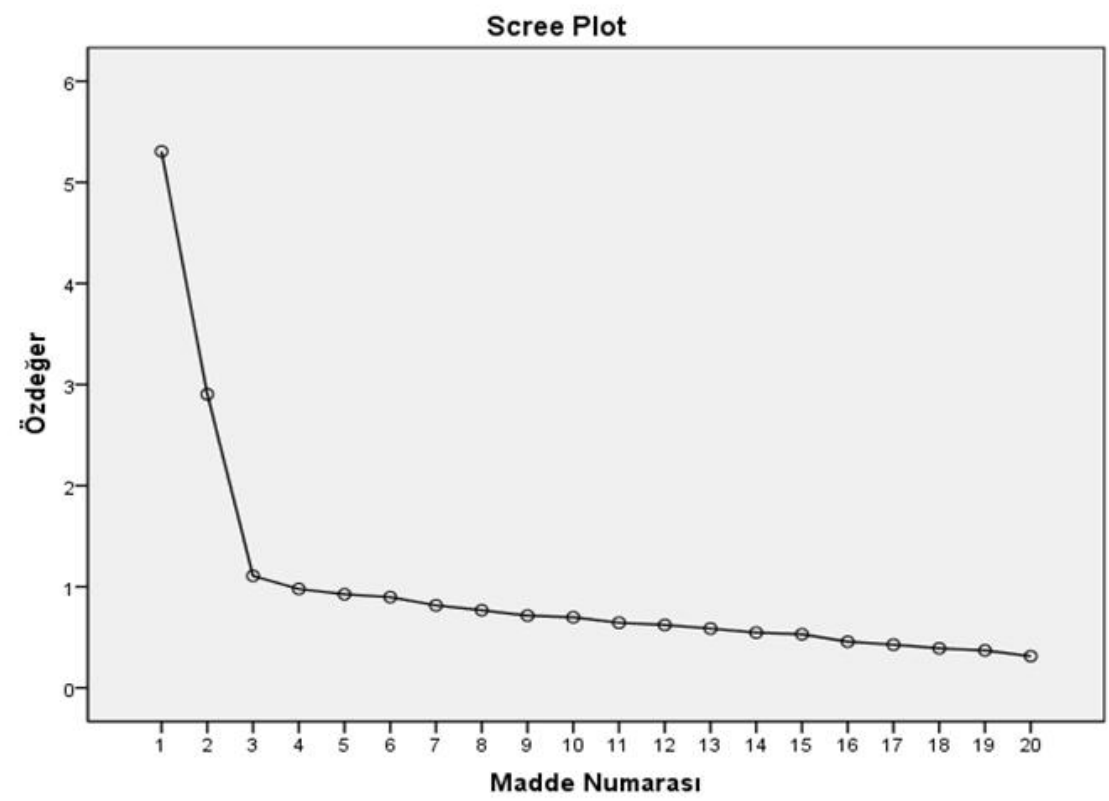

Şekil 1. Özdeğer Grafiği Faktör Yapısı Şekli

Son durumda; ölçekte kalan 20 maddenin özdeğer grafiği yukarıda verilen Şekil 1'deki gibi elde edilmiştir.

Tablo 1. Ölçekte Yer Alan Maddelerin Döndürülmüş Faktör Yükleri

\begin{tabular}{llll}
\hline Madde No & F1 & Madde No & F2 \\
\hline 2 & .62 & 1 & .54 \\
9 & .59 & 3 & .71 \\
11 & .77 & 8 & .62 \\
15 & .73 & 10 & .68 \\
17 & .70 & 16 & .43 \\
20 & .55 & 18 & .67 \\
23 & .63 & 19 & .43 \\
28 & .65 & 25 & .62 \\
37 & .61 & 27 & .67 \\
39 & .33 & 29 & .58 \\
\hline
\end{tabular}

Varimax döndürme işlemi sonucunda yapılan incelemelerde (bkz. Tablo1); davranış boyutunu açıklayan birinci faktörün 10 maddeden $(2$, $9,11,15,17,20,23,28,37,39)$, tutum boyutunu açılayan ikinci faktöründe 10 maddeden $(1,3$, $8,10,16,18,19,25,27,29)$ oluştuğu belirlenmiştir. Birinci faktördeki maddelerin faktördeki yük değerleri .33-.77 arasında değişmektedir. İkinci faktörde yer alan yük değerlerin ise .43-
.71 arasında değiştiği görülmektedir. Ölçeğin son halinde her bir boyutta yer alan maddelerin madde numaraları yukarıdaki sıraya paralel olarak davranış boyutu için, $(2,5,7,8,10,13$, $14,17,19,20)$ ve tutum boyutu için $(1,3,4,6,9$, $11,12,15,16,18)$ şeklinde düzenlenmiştir. Ölçeğin son hali için hesaplamalarda olumsuz ifade içeren 12. madde ters kodlanmalıdır. 
İlköğretim öğrencileri için çevre okuryazarlığ ölçeğinin iki faktörlü yapı gösterdiği belirlenmiş ve Tablo 2'de faktörlerin varyansları sunulmuştur. İki faktörün açıkladığı toplam varyans \%41.05'dir. Belirlenen faktörlerden birincisi toplan varyansın $\% 26.53$ ünü, ikinci faktör ise; \%14.52'sini açıklamaktadır. Büyüköztürk'e (2011) göre; ölçek tek faktörden oluşuyorsa açıklanan varyansın \%30, çok faktörlü ölçeklerde ise faktör varyans değerinin $\% 41$ 'in üzerinde olması yeterli görülmektedir (Kline, 1994).

Tablo 2. Ölçeği Oluşturan Faktörlerin Varyansı

\begin{tabular}{lll}
\hline Faktör & Varyans Yüzdesi & Toplam Varyans Yüzdesi \\
\hline Faktör 1 & 26.53 & 26.53 \\
Faktör 2 & 14.52 & 41.05 \\
\hline
\end{tabular}

\section{2. İç tutarlık katsayısı}

Ölçeğin güvenirlik hesaplamaları için Cronbach-alpha iç tutarlılık katsayıları hesaplanmıştır. Alpha değeri 0 ile 1 arasında değerler almaktadır ve kabul edilebilir olması için bu değerin en az .70 olması gerekmektedir (Altunışık, Coşkun, Bayraktaroğlu ve Yıldırım,
2010). İlköğretim öğrencileri için 20 maddelik çevre okuryazarlığı ölçeğinin toplam iç tutarlılık katsayısı .84 olarak hesaplanmıştır. Ölçeğin davranış boyutu için iç tutarlılık katsayısı .82, tutum boyutu için ise .79 olarak bulunmuştur. Bu sonuçlara göre; ölçeğin iç tutarlılık katsayılarının kabul edilebilir düzeyde olduğu görülmektedir.

Tablo 3. Ölçeğin Madde-Toplam Korelasyon Katsayıları ve Madde Silindiğindeki Cronbach Alpha Değerleri

\begin{tabular}{|c|c|c|c|}
\hline Alt Boyut & Madde No & $\begin{array}{c}\text { Madde -Toplam } \\
\text { Korelasyonu }\end{array}$ & $\begin{array}{l}\text { Madde Silindiğinde } \\
\text { Cronbach Alpha Değeri }\end{array}$ \\
\hline \multirow{10}{*}{ Davranış } & 2 & .61 & .81 \\
\hline & 9 & .62 & .81 \\
\hline & 11 & .71 & .80 \\
\hline & 15 & .68 & .80 \\
\hline & 17 & .68 & .80 \\
\hline & 20 & .61 & .81 \\
\hline & 23 & .65 & .81 \\
\hline & 28 & .67 & .80 \\
\hline & 37 & .57 & .82 \\
\hline & 39 & .47 & .83 \\
\hline \multirow{10}{*}{ Tutum } & 1 & .58 & .77 \\
\hline & 3 & .63 & .76 \\
\hline & 8 & .59 & .77 \\
\hline & 10 & .65 & .76 \\
\hline & 16 & .52 & .78 \\
\hline & 18 & .66 & .76 \\
\hline & 19 & .55 & .79 \\
\hline & 25 & .57 & .77 \\
\hline & 27 & .67 & .76 \\
\hline & 29 & .63 & .76 \\
\hline
\end{tabular}


Ölçeğinin madde toplam korelasyonları ve madde silindiğinde Cronbach Alpha değerleri Tablo 3'te verilmiştir. Madde toplam korelasyonları davranış alt boyutu için .47-.71 ve tutum alt boyutu için $.52-.67$ aralığında değiştiği görülmektedir. Bunun yanında madde silindiğinde Cronbach Alpha değerleri incelendiğinde sadece iki maddenin güvenirlik katsayısını geliştirdiği görülmektedir. Bu maddeler 19 “Çevre sorunları ilgimi çekmez" ve 39 "Çöplerimi yerlere atmamak için ceplerimde ya da çantamda taşırım" maddeleridir. Her iki mad- de silindiğinde güvenirlik katsayısı çok yükselmediğinden bu maddelerin ölçekte yer almasına karar verilmiştir.

\subsection{Doğrulayıcı faktör analizi (DFA)}

AFA ile 2 faktör olmak üzere 20 maddeden oluştuğu belirlenen ölçeğin faktör modelinin uygunluğunun test edilmesi amaciyla doğrulayıcı faktör analizi yapılmıştır. Bu amaca bağlı olarak 401 öğrenciden oluşan bir gruptan elde edilen veriler üzerinde birinci düzey doğrulayıcı faktör analizi uygulanmıştır.

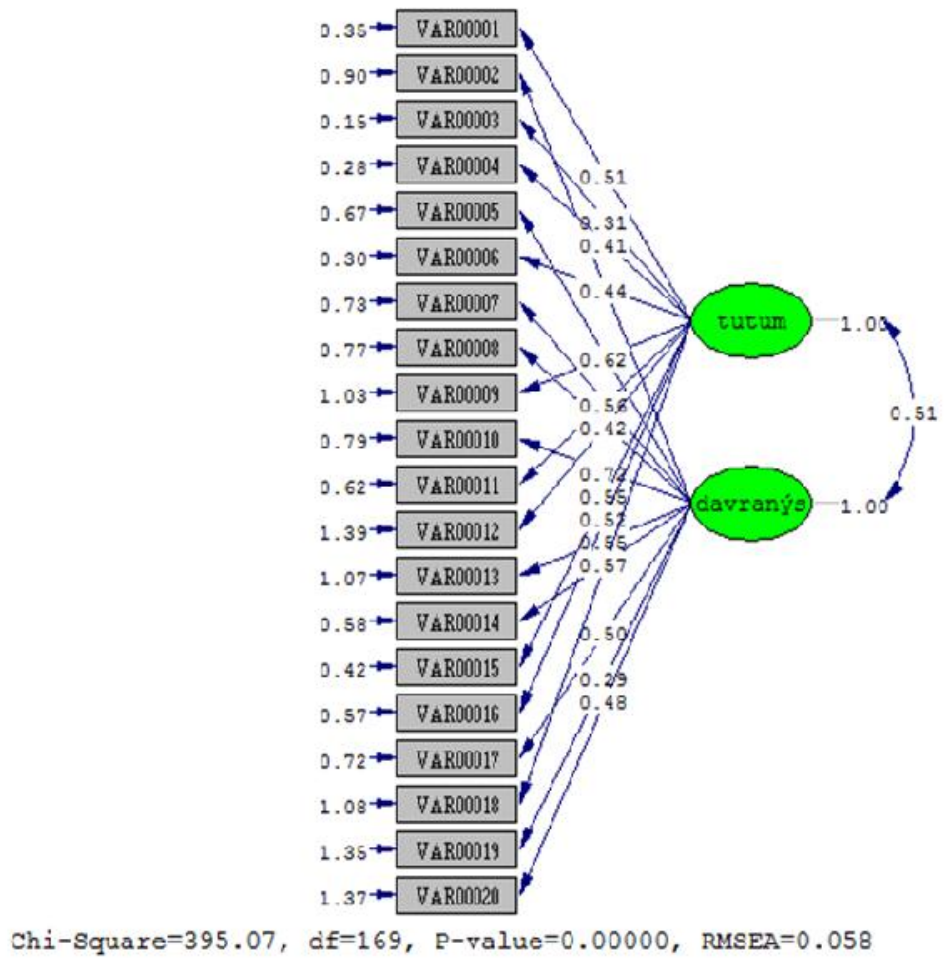

Şekil 2.Ölçeğin Birinci Düzeyde Doğrulayıcı Faktör Analizi Ait Diyagram

CFI, NFI, NNFI, RFI ve IFI indeksleri için $\geq .90$ değeri kabul edilebilir uyuma ve $\geq .95$ değeri mükemmel uyuma işaret etmektedir (Bentler, 1980; Bentler \& Bonett, 1980; Hu \& Bentler, 1999; Marsh, Hau, Artelt, Baumert \& Peschar, 2006). RMSEA değeri için $\leq .06$ değeri kabul edilebilir uyum ve $\leq .05$ değeri mükemmel uyum ölçütü olarak alınmaktadır . RMR değeri için ise $\leq .05$ değeri mükemmel uyuma ve $\leq .80$ değeri kabul edilebilir uyuma işaret etmektedir (Hu \& Bentler, 1999; Brown, 2006). x2 / sd değeri için ise, $\leq 2.5$ mükemmel uyuma işaret etmektedir (Kline, 2005). Sinırlandırma olmadan yürütülen doğrulayıc faktör analizi sonucunda ölçeğin uyum indeksi değerleri $\chi 2=$ $395.07(\mathrm{~N}=401, \mathrm{sd}=169, \mathrm{p}=.00), \chi 2 / \mathrm{sd}=2.33$, RMSEA $=0.058, \quad \mathrm{RMR}=0.070, \quad \mathrm{CFI}=0.96$, RFI $=0.91, \quad \mathrm{NFI}=0.92, \quad \mathrm{IFI}=0.96$ ve $\mathrm{NNFI}=0.95$ 
olarak bulunmuştur. Doğrulayıcı faktör analizi sonucunda elde edilen uyum indeks değerleri kriterlerle karşılaştırıldığında; uyum indekslerinin bazılarının kabul edilebilir, bazılarının ise mükemmel uyum düzeyinde olduğu görülmektedir. Bu doğrultuda ölçekte yer alan maddelerin ilgili yapıyla olan modellerinin uygun olduğu sonucuna ulaşılmıştır.

Şekil 2'de ölçeğin iki boyutlu modeline ait faktör yüklerinin yer aldığı diyagrama yer verilmiştir. $\mathrm{Bu}$ model diyagramında tutum boyutunun faktör yükleri. 29- .72, davranış boyutunun .31-. 72 aralığında değişmekte olduğu görülmektedir.

\section{TARTIŞMA}

Çevre eğitimi ile gerçekleştirilmeye çalışılan çevre okuryazarlı̆̆ı; ömür boyu eğitim anlayışını içermektedir. Bu kapsamda var olan eğitim okul öncesinden başlayarak örgün ve yaygın eğitim dönemlerini kapsamaktadır. En önemli basamaklarından birini ise okuma yazmayı öğrendikten sonra çevresiyle daha ilgili hale gelen ilköğretim öğrencileri oluşturmaktadır. Oysaki ülkemizde çevre okuryazarlığına ilişkin araştırmaların bir kısmı üniversite öğrencilerini veya öğretmen adaylarını kapsamaktadır. Bu doğrultuda yürütülen birçok çalışmada çeşitli çevre okuryazarlığı ölçekleri kullanılarak öğretmen, öğrenci ve öğretmen adaylarının çevre ve çevre sorunlarına yönelik tutum, davranış, bilgi ve algılarının (Bradley, Waliczek ve Zajicek, 1999; Bülbül, 2007; Dechano, 2006; İbiş, 2009; Kaplowitz ve Levine, 2005; Selvi, 2007) ve çevre okuryazarlık düzeylerinin (Gayford, 2002; Teksöz, Şahin ve Ertepınar, 2010; Timur, 2011; Owens, 2000; Pe'er, Goldman ve Yavetz, 2007) belirlenmesi amaçlanmıştır. Ayrıca bu çalışmalara ek olarak eğitim-öğretim faaliyetlerinde yürütülen farklı öğretim yöntemlerinin çevre okuryazarlılık düzeyine nasıl etki ettiğine yer veren çalışmalara (Kışoğlu, 2009; Özsoy, 2010) ve çevre okuryazarlılığının çeşitli değiş- kenlere bağlı kalarak incelendiği çalışmalara da rastlanmıştır (Karatekin ve Aksoy, 2012; Koç ve Karatekin, 2013; Ökesli, 2008; Öztürk, 2009). Literatür incelendiğinde; büyük çoğunluğu adaptasyon çalışmaları olan birçok ölçek geliştirme çalışması olduğu sonucuna ulaşılmıştır (Berberoğlu ve Tosunoğlu, 1995; Kaplowitz ve Levine, 2005; Kışoğlu, 2009; Selvi, 2007; Timur ve Yılmaz, 2013; Teksöz ve diğerleri, 2010; Tuncer ve diğerleri, 2009) Bu şekilde çevre okuryazarlığı ile ilgili çeşitli verilerin eldesinde ölçeklerin kullanıldığı birçok çalışma gerçekleştirilmesine rağmen genel olarak bu çalışmalarda yer alan çevre okuryazarlığı ölçeğinin aynı olduğu fark edilmiş olup, bu bir sınırlılık olarak görülmektedir. $\mathrm{Bu}$ çalışma sonucunda geliştirilen ölçek bu sınırlılığın ortadan kalkmasına ve çevre okuryazarlığına ilişkin geliştirilen ölçeklerin çeşitlendirilmesine katkı sağlamıştır. Ayrıca ilköğretim öğrencileri için hazırlanan bu ölçek mevcut haliyle farklı örneklem gruplarında uygulanabilir ve ölçeğe ilişkin geçerlik ve güvenirlik çalışmaları farklı örneklem gruplarında ve eğitim kademelerinde tekrarlanabilir.

\section{SONUÇ}

Araştırmada ilköğretim öğrencilerinin çevre okuryazarlıklarını belirlemek amacıyla bir ölçek geliştirilmesi amaçlanmıştır. Başlangıçta 39 maddeden oluşan ölçekte; yapılan çalışma ve analizler sonucunda madde sayısı indirgenerek 20 madde içeren 5'li Likert tipinde bir ölçek elde edilmiştir. Araştırma sonucunda geliştirilen ölçek; her biri 10'ar maddeden oluşan, tutum ve davranış olmak üzere iki alt boyuttan oluşmaktadır. Ölçek maddeleri sırasıyla 5, 4, 3, 2, 1 şeklinde puanlandırılmıştır. Ölçeğin her iki boyutundan alınabilecek en düşük puan 20 iken, en yüksek puan 100 puandır. Güvenirlik çalışmaları kapsamında yapılan analizler sonucunda elde edilen iç tutarlık katsayısı incelendiğinde de; ölçeğin güvenilir 
olarak kullanılabileceğini göstermiştir. Taslak form ile yapılan analizler sonucunda geliştirilen ölçek arasındaki madde sayılarındaki farklılığın sebebi, farklı alan uzmanlarının da görüşünün alınmaması ve pilot çalışmanın daha büyük bir örneklem grubu üzerinde uygulanmamasından kaynaklanmış olabileceği düşünülmektedir. Sonuç olarak bu verilere göre;

\author{
İlköğretim Öğrencileri İçin Çevre Okuryazarlığ \\ Ölçeği ilköğretim öğrencilerinin çevre okurya- \\ zarlığının davranış ve tutum boyutunu belirle- \\ yebilecek geçerli ve güvenilir bir ölçektir. Mev- \\ cut sistemde bu ölçek ilköğretim ikinci kademe \\ (ortaokul) öğrencileri için kullanılabilir bir \\ ölçektir.
}

\section{Kaynakça}

Alım, M. (2006). Avrupa birliği üyelik süresince Türkiye'de çevre ve ilköğretimde çevre eğitimi. Kastamonu Ĕ̈itim Dergisi, 14(2), 599-616.

Altunışık, R., Coşkun, R., Bayraktaroğlu, S. ve Yıldırım, E. (2010). Sosyal Bilimlerde Araştırma Yöntemleri (6. Bask1). Sakarya:Sakarya Yayıncılık.

Balkan Kıyıcı, F. (2009). Çevre eğitimi. V. Sevinç (Editör), Eğitim fakülteleri için genel çevre bilimi, s. 175183. Ankara:Maya Akademi.

Bentler, P. M. (1980). Multivariate analysis with latent variables: Causal modeling. Annual Review of Psychology, 31, 419-456.

Bentler, P.M. ve Bonett, D.G. (1980). Significance tests and goodness of fit in the analysis of covariance structures. Psychological Bulletin, 88, 588-606.

Berberoglu, G. ve Tosunoglu, C. (1995). Exploratory and confirmatory factor analyses of an environmental attitude scale (EAS) for Turkish university students. The Journal of Environmental Education, 26(3), 40-43.

Bradley, J. C., Waliczek, T. M. ve Zajicek, J. M. (1999). Relationship between environmental knowledge and environmental attitude of high school students. The Journal of Environmental Education, 30(3), $17-21$.

Braus, J. A. ve Wood, D. (1993). Environmental education in schools : Creating a program that works!. Washington DC: Peace Corps.

Brown, T. A. (2006). Confirmatory Factor Analysis for Applied Research. (First Edition). NY: Guilford Publications, Inc.

Bülbül, Y. (2007). Ortaöğretim çevre ve insan dersinde işbirlikli öğrenme yönteminin çevreye yönelik tutumlara ve erişiye etkisi. Yayınlanmamış Yüksek Lisans Tezi, Onsekiz Mart Üniversitesi, Çanakkale.

Büyüköztürk, Ş. (2011). Sosyal bilimler için veri analizi el kitabı. Ankara: Pegem A Yayıncılık.

DeChano, L. M. (2006). A multi-country examination of the relationship between environmental knowledge and attitudes. International Research in Geographical and Environmental Education, 15(1), 15.

Erten, S. (2005). Okul öncesi öğretmen adaylarında çevre dostu davranışların araştırılması. Hacettepe Üniversitesi Ĕ̆itim Fakültesi Dergisi, 28, 91-100.

Gayford, C. (2002). Controversial environmental issues: a case study for the professional development of science teachers. International Journal of Science Education, 24(11), 1191-1200.

Gündüz, T. (1998). Çevre sorunları . Ankara: Gazi Kitabevi.

Güneş, Ş. (2001). Karadeniz'de çevresel iş birliği, 1992 Bükreş Sözleşmesi. ODTü Gelişme Dergisi, 28(3-4), 311-337. 
Hu, L.T. ve Bentler, P.M. (1999). Cutoff criteria for fit indexes in covariance structural analysis: Conventional criteria versus new alternatives. Structural Equation Modeling, 6, 1-55.

İbiş, S. (2009). Biyoloji öğretmen adaylarının küresel ve ulusal çevre sorunları hakkındaki görüşleri. Yayınlanmamış Yüksek Lisans Tezi, Gazi Üniversitesi, Ankara.

Kaiser, H. F. (1974). An index of factorial simplicity. Psychometrika, 39(1), 31-36.

Kaplowitz, M. D. ve Levine, R. (2005). How environmental knowledge measures up at a big ten university. Environmental Education Research, 11(2), 143-160.

Karatekin, K. ve Aksoy, B. (2012). Sosyal Bilgiler Öğretmen Adaylarının Çevre Okuryazarlık Düzeylerinin Çeşitli Değişkenler Açısından İncelenmesi (Examination of Teacher Candidates of Social Studıes' Environmental Literacy Level in Terms of Various Variables). Literature And History Of Turkish Or Turkic, 7(1), 1423-1438.

Kışoğlu, M. (2009). Öğrenci merkezli öğretimin öğretmen adaylarının çevre okuryazarlĭğ düzeyine etkisinin araştırılması. Yayınlanmamış Doktora Tezi, Atatürk Üniversitesi, Erzurum.

Kışoğlu, M., Gürbüz, H., Sülün, A., Alaş, A. ve Erkol, M. (2010). Çevre okuryazarlığı ve çevre okuryazarlığı ile ilgili türkiye'de yapılan çalışmaların değerlendirilmesi. International Online Journal of Educational Sciences, 2(3), 772-791.

Kibert, N. C. (2000). An analysis of the correlations between the attitude, behavior, and knowledge components of environmental literacy in undergraduate university students. Unpublished Master Thesis, The Graduate School Of The Unıversity Of Florıda, Unıversity Of Florida.

Kiss, A. C. ve Shelton, D. (1991). International Environmental Law (p. 107). New York: Transnational Publishers.

Kline, P. (1994). An Easy Guide to Factor Analysis. Thousand Oaks (CA):Sage Publications.

Kline, R. B. (2005). Principles an Practice of Structural Equation Modeling. (Second Edition). NY: Guilford Publications, Inc.

Koç, H. ve Karatekin, K. (2013). Coğrafya öğretmen adaylarının çevre okuryazarlık düzeylerinin çeşitli değişkenler açısından incelenmesi. Marmara Coğrafya Dergisi, 28, 139-174.

Marsh, H.W., Hau, K.T., Artelt, C., Baumert, J. ve Peschar, J.L. (2006). OECD's brief self-report measure of educational psychology's most useful affective constructs: Cross-cultural, psychometric comparisons across 25 countries. International Journal of Testing, 6(4), 311-360.

Owens, S. (2000). 'Engaging the public': information and deliberation in environmental policy. Environment and planning A, 32(7), 1141-1148.

Ökesli, T. F. (2008). Relationship between primary school students' environmental literacy and selected variables in bodrum. Unpublished Master Thesis, Middle East Technical University, Ankara.

Özata Yücel, E. ve Özkan, M. (2013). 2013 fen bilimleri programının 2005 fen ve teknoloji programıla çevre konuları açısından karşılaştırılması, Uludă̆ Üniversitesi Ĕ̆itim Fakültesi Dergisi, 26(1), 237265.

Özsoy, S. (2010). Effects of eco-school applicatıon on elementary school students' environmental hteracy levels. Unpublished Dissertation, Middle East Technical University, Ankara.

Öztürk, G. (2009). Investigating pre-service teacher's environmental literacy through their epistemological beliefs. Unpublished Master Thesis, Middle East Technical University , Ankara.

Pe'er, S., Goldman, D. ve Yavetz, B. (2007). Environmental literacy in teacher training: attitudes, knowledge, and environmental behavior of beginning students. The Journal of Environmental Education, 39(1), 45-59. 
Roth, C.E. (1992). Environmental Literacy: Its Roots, Evolution and Directions in the1990s. Columbus, OH: ERIC/CSMEE Publications. (ERIC Number: ED348235).

Selvi, M. (2007). Biyoloji öğretmeni adaylarının çevre kavramları ile ilgili algılamalarının değerlendirilmesi. Yayınlanmamış Doktora Tezi, Gazi Üniversitesi, Ankara.

Sevinç,V., Balkan Kıyıcı, F., Altaş, S.S. ve Altınöz, N. (2010). Fen bilgisi öğretmen adaylarının çevre okuryazarlık düzeylerinin belirlenmesi, International Conferance New Horizons in Education, KKTC.

Smith, A. (2001). Early childhood- A Wonderful time for science learning. Australian Primary E Junior Journal, 17(2), 52-55.

Soran, H., Morgil, İ., Yücel, S., Atav, E. ve Işık, S. (2000). Biyoloji öğrencilerinin çevre konularına olan ilgilerinin araştırılması ve kimya öğrencileri ile karşılaştırılması. Hacettepe Üniversitesi Ĕ̆itim Fakültesi Dergisi, 18, 128-139.

Teksöz, G., Şahin, E. ve Tekpınar, H. (2010). Çevre okuryazarlığı, öğretmen adayları ve sürdürülebilir bir gelecek. Hacettepe Üniversitesi Eğitim Fakültesi Dergisi, 39, 307-320.

Timur S. (2011). Fen bilgisi öğretmen adaylarının çevre okuryazarlık düzeylerinin belirlenmesi. Yayımlanmamış Doktora Tezi, Gazi Üniversitesi, Ankara.

Timur, S. ve Yılmaz, M. (2013). Çevre Davranış Ölçeğinin Türkçe’ye Uyarlanması. Gazi Eğitim Fakültesi Dergisi, 33(2), 317-333.

Trudel, M. (1995). IUCN in environmental education in western Africa and the Sahel. J. Palmer, W. Goldstein, \& A. Curnow (Eds.), Planning education to care for the earth p.74-83. Gland, Switzerland and Cambridge, UK:IUCN Publications.

Tuncer, G., Tekkaya, C., Sungur, S., Cakiroglu, J., Ertepinar, H. ve Kaplowitz, M. (2009). Assessing preservice teachers' environmental literacy in Turkey as a mean to develop teacher education programs. International Journal of Educational Development, 29(4), 426-436.

Turan, A. ve Güler, M. (2013, Eylül). Türkiye'de Sürdürülebilir Çevre Politikaları: İklim Değişikliği Örneği. International Conference On Eurasian Economies, St. Petersburg-Russia.

UNESCO (1977). The Tbilisi Declaration: Final report intergovernmental conference on environmental education. Organized by UNESCO in corporation with UNEP, Tbilisi.

Yücel, S. A. ve Morgil F. İ. (1998). Yüksek öğretimde çevre olgusunun araştırılması. Hacettepe Üniversitesi Ĕ̆itim Fakültesi Dergisi, 14, 84-91. 


\section{Extended Summary}

Among major environmental problems; human have insufficient knowledge concerning environment therefore they develop negative attitude and behavior. Educating environmental literate person can be seen as the most important factor to prevent and solve environmental problems. To educate environmental literate person and to reach livable environment determining human's environmental literacy level is important necessity. However when the literature is examined, developed scales intend to assess university students' environmental literacy, there is no much scale developed to assess secondary school student's level of environmental literacy. Process of educating people as environmental sensitive and environmental literate should begin in family, in every step of pre-school and primary school these abilities and skills should be taught. The purpose of this research is to develop a scale in which secondary school students' environmental literacy levels will be determined.

This research is aimed to develop a scale to assess secondary school student's environmental literacy. The sample of the research was consisted of 377 students of six public secondary schools. The study was done in 2010-2011 spring semester. In the process of developing scale five steps followed. These steps are: literature review, forming item pool, getting field expert opinion, administering surveys, running factor analysis and reliability tests. The researchers first of all created an item pool that consists of 45 items. A draft form with 39 items was created after the necessary corrections had been made based on the expert opinions. To test the construct validity of environmental literacy scale for secondary school students, exploratory factor analysis was run.

The results of the Explanatory Factor Analysis on a 20 item five-point Likert type scale showed that the instrument consists of two dimensions those attitude and behavior. Each dimensions have 10 items. Reliability of the scale which is developed for primary school students and have 20 items is .84. Reliability of behavior dimension has .82 reliability coefficient and attitude dimension has .79 reliability coefficient. These results show that scale has highly reliable, and scale can be used to assess environmental literacy.

Student can answer to scale's items as strongly agree, agree, neutral, disagree and strongly disagree. The items in scale is graded as 5, 4, 3,2, 1 . Possible maximum point is 100 point and possible minimum point is 20. As a result, environmental literacy scale for secondary school students is reliable and valid scale to assess primary schools environmental literacy in attitude and behavior dimensions. Reliability and validity of the scale can be test in different sample group and different educational level. 